\title{
Managerial Ownership, Horizontal Agency Costs and Monitoring Mechanisms
}

Conference Paper · August 2016

DOI: $10.15405 /$ epsbs.2016.08.37

CITATIONS

0

1 author:

Arowolo Oluyemisi

Universiti Utara Malaysia

3 PUBLICATIONS 0 CITATIONS

SEE PROFILE
READS

12 


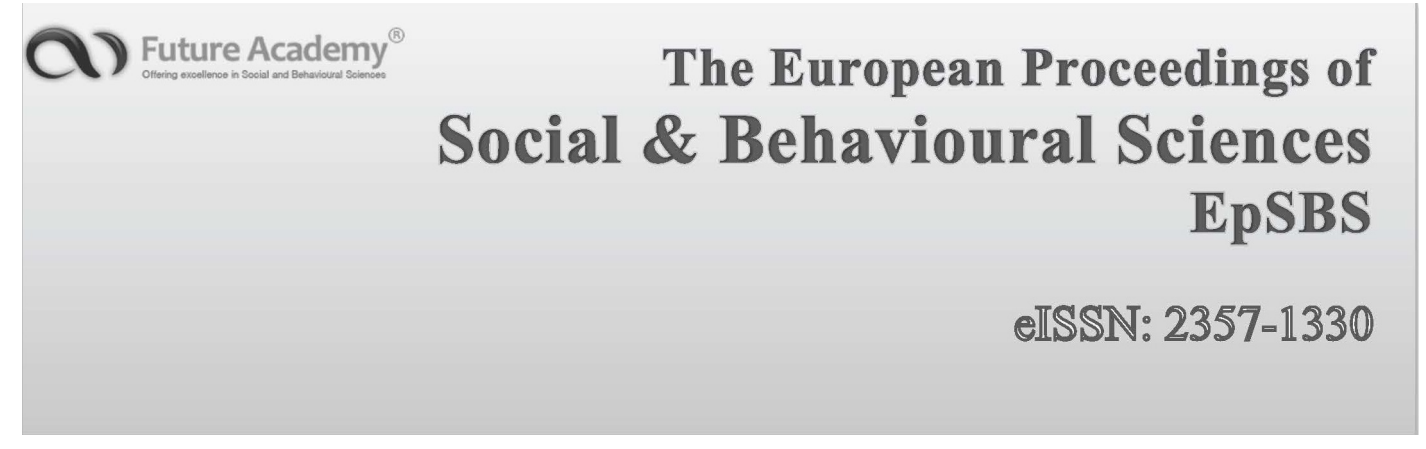

ISSC 2016 : International Soft Science Conference

\title{
Managerial Ownership, Horizontal Agency Costs and Monitoring Mechanisms
}

\author{
Rachael Oluyemisi Arowolo a*, Ayoib B Che-Ahmad ${ }^{\mathrm{a}}$ \\ * Corresponding author: Rachael Oluyemisi Arowolo, aroldaot@gmail.com \\ ${ }^{a}$ School of Accountancy, College of Business, Universiti Utara Malaysia, Kedah, Malaysia, aroldaot@gmail.com
}

\begin{abstract}
http://dx.doi.org/10.15405/epsbs.2016.08.37

Company operations are characterized by information asymmetry between the agent (management and the board of directors) and the principal (shareholders). The purpose of this study is to empirically examine the extent of monitoring mechanisms in Nigerian non-financial listed companies and the impact of managerial ownership and horizontal-agency-costs on the mechanisms. The study adopted a quantitative approach and distributed 332 questionnaires to 166 non-financial listed companies to obtain a cross-sectional data for the internal auditing. The findings give credible evidence that the horizontal-agency-cost is positively significant while managerial ownership is negatively significant. The findings of this study suggest policy implications for the monitoring roles of the board of directors as well as the internal and external auditors. Likewise, the findings are useful to the regulatory agencies and government for a further review of corporate governance guidelines. This paper contributes to knowledge by combining the three dimensions of monitoring mechanisms (directorship, internal and external auditing) in Sub-Saharan Africa.
\end{abstract}

(C) 2016 Published by Future Academy www.FutureAcademy.org.uk

Keywords: Monitoring mechanisms; Managerial ownership; Horizontal-agency-costs; Type II agency problem.

\section{Introduction}

Monitoring mechanisms as contained in each country's code of corporate governance are designed to resolve agency problems. Monitoring mechanisms can be internal or external (Huson, Parrino, \& Starks, 2001). Monitoring mechanisms are applied to align the activities of the management and controlling shareholders with the interests of other shareholders (Kao, Chiou, \& Chen, 2004). The relationship between the management and shareholders is characterized by information asymmetry, 
moral hazard and goal conflicts (Slyke, 2006). Failure to align the interests of the management, controlling shareholders, a board of directors and other investors results in high agency costs. Such failures account for the incidence of the financial crisis and frequent business failure, which suggest the need for investors' protection (Mustapha \& Che-Ahmad, 2011). Therefore, monitoring mechanisms are meant to constrain ineffectiveness that can result from the agency problems ( $\mathrm{He} \& \mathrm{Ho}, 2010)$. Therefore, monitoring mechanisms are required to mitigate the agency costs.

There are speculations in the extant literature that good corporate governance enhances internal and external monitoring mechanisms (Huson et al., 2001). Hence, the continuance of reviews of codes of corporate governance to ensure adequacy of monitoring mechanisms (Huson et al., 2001).

Despite the increasing importance of monitoring mechanisms and continuance review of codes of corporate governance, the incidence of business failures and poor economy persist especially in the Sub-Saharan Africa. There are many studies on monitoring mechanisms (Kao et al., 2004; Slyke, 2006; Azim, 2012; Anderson, Francis, \& Stokes, 1993). However, most of this studies are from developed and transiting countries like U.S, U.K, and Malaysia, leaving the developing countries like Nigeria far behind. Many of these studies address only one or two of the three dimensions of the monitoring mechanisms (directorship, internal auditing, and external auditing). Many that studied directorship did it in part. Examples are studies of audit committee only, independent directors alone, a part of board composition and one or two parts of board activities.

There is a dearth of research on monitoring mechanisms in Nigeria. There are few studies on ownership (Ehikioya, 2009; Uadiale, 2010) in Nigeria. However, to the best of the knowledge of the researchers, none of the studies is on horizontal-agency-costs. Neither is there any of the studies that tested monitoring mechanisms as a combination of directorship, internal auditing and external auditing in Nigeria.

2011 SEC code of corporate governance supports the need for the three dimensions of monitoring mechanisms (directorship, internal auditing, and external auditing). Nigerian Securities and Exchange Commission (SEC) maintains that weak corporate governance is responsible for some corporate failures in Nigeria. It, therefore, plan to fully enforce the new code as the new code makes provision for accountability, transparency and good corporate governance in Nigerian companies.

Reports of business failures, mergers, and bankruptcy within the last decade have been very disturbing. Reasons for these miseries are inadequate monitoring and enforcement of the code of corporate governance (Nworji, Adebayo, \& Adeyanju, 2011). Therefore, this paper aims to empirically test the relationship between organizational attributes (in the context of managerial ownership and type II agency problem) and monitoring mechanisms (directorship, internal auditing, and external auditing). However, this is the first published study, to the best of the knowledge of the researchers that has studied monitoring mechanisms from this perspective in Nigeria. Likewise, this will be the first to test type II agency problem in Nigeria.

The section following this part of the paper reviews the literature and develop hypotheses. Next to this is the section that discusses methodology, followed by result and discussion section, and then, the conclusion section. 


\section{Literature Review}

The Nigerian Securities and Exchange Commission (SEC), conducts oversight functions over all listed companies in Nigeria. The companies are incorporated under the Companies and Allied Matters Act (1990 and as amended in 2004). However, SEC is the regulatory authority responsible for regulating the activities of the companies (financial and non-financial) especially as it relates to the capital market. The main objective of SEC is to ensure that investors are protected. SEC revised 2003 code of corporate governance to inject fairness, efficiency and transparency into the capital market and reduce the systematic risks of the market. The government approved the new code of corporate governance, 2011 SEC Code for this purpose (SEC, 2011). The commission encouraged both the public and private companies to apply the principles in the code of corporate governance as appropriate in the conduct of the affairs of each company. SEC in line with agency theory seeks to find solutions to information asymmetry, underlined by corruption through expropriation of assets by one party at the detriment of the other. It also seeks in line with stakeholders theory to ensure adequate provisions for the interests of all parties to the contracts of a company.

There are many definitions for monitoring mechanisms in the existing literature (Huson et al., 2001; Kao et al., 2004; Slyke, 2006; Mustapha \& Che-Ahmad, 2011). However, it is clear from all the definitions that shareholders rely on the monitoring mechanisms to resolve agency problems in companies with their investments. A study by Azim (2012) on the impact of corporate governance mechanisms on company performance claims that monitoring mechanisms can effectively reduce agency problem. The study of Choi, Lee, and Sonu (2013), examines factors that determine human resource investment in internal controls. The study finds that good monitoring mechanisms reduce the need for a company to invest much on intellectual capital to have an effective internal control. The study of Anderson et al. (1993), investigates how auditing and directorships relate to the demand for monitoring. The study claims that directorship, internal and external monitoring are part of monitoring mechanisms companies use to ensure good corporate governance. Generally, monitoring mechanisms helps to ensure good corporate governance by reducing agency costs through alignment of the interests of management and shareholders (Huson et al., 2001; Slyke, 2006; Choi et al., 2013; SEC, 2011).

This paper, therefore, examines how monitoring mechanisms (directorship, internal and external auditing) resolve agency problems in the non-financial sector of Nigeria concerning managerial ownership and horizontal-agency-costs.

\section{Hypotheses Development}

\subsection{Managerial Ownership (MO)}

Agency theory suggests that management is characterized by callous attitudes resulting in the expropriation of company assets and information asymmetry. Extant literature has shown that attitudes of a staff-manager differ from his attitudes as an owner-manager (Jensen \& Meckling, 1976; Jusoh \& Che-Ahmad, 2014). These studies suggest that managerial ownership is an incentive for management to align its interests with the shareholders' interests. By so doing, there may be less demand for monitoring because there is no separation between ownership and control. However, the extent of the 
alignment is determined by the degree of the ownership (Jusoh \& Che-Ahmad, 2014). The greater the MO, the less severe the agency problem (Amran \& Che-Ahmad, 2013). However, this could be to the detriment of the minority shareholders.

The study of Mustapha and Che-Ahmad (2011) investigates agency theory and managerial ownership (MO) using data from 235 Malaysian listed companies. The study finds that MO inversely relates to total monitoring costs. Thus, the study suggests that there may be less demand for monitoring in a company with owner-manager. However, the study of Jusoh and Che-Ahmad (2014) finds that MO negatively and significantly relates to company performance.

The expectation, therefore, is that managerial ownership (MO) is likely to align the shareholders and agents' interests, thereby reducing the cost of monitoring. This study, therefore, considers related hypotheses as shown below:

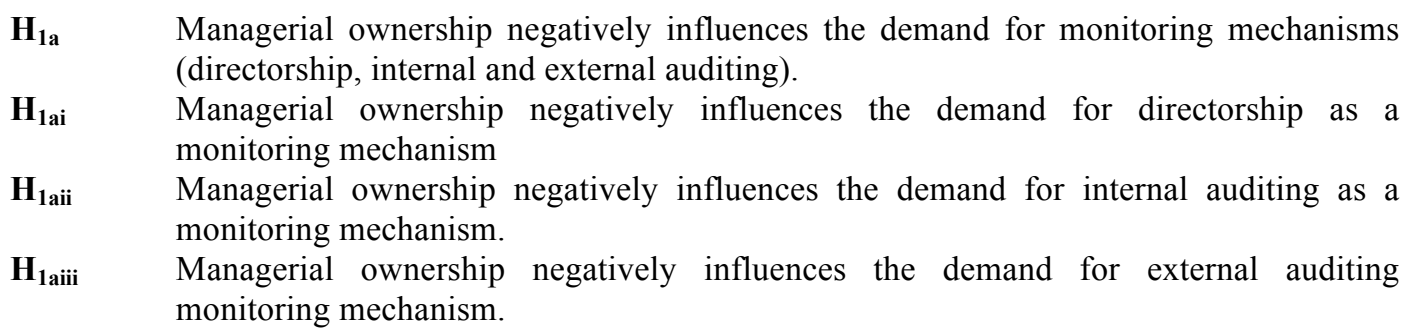

\subsection{Block-holding (Horizontal-agency-costs)}

Stakeholders' theory suggests that no stakeholder should be rendered a means to an end because; all stakeholders have claims on the company. Existing literature reveal that block-holding is an important organizational attribute for effective monitoring of management activities (Mustapha \& Che-Ahmad, 2013; Reuer, Tong, \& Wu, 2012) These literature suggest different types of block-holders, such as institutional (Mustapha \& Che-Ahmad, 2013); individual (Eng \& Mak, 2003); inside/outside (Jensen \& Meckling, 1976); independent/executive (R. C. Anderson, Mansi, \& Reeb, 2003); multiple (Connelly, Hoskisson, Tihanyi, \& Certo, 2010); second-largest (Chen, Firth, Gao, \& Rui, 2006). Each of these types of block-holding has a distinct role to play in good corporate governance (Hope, 2013).

The study of Jensen and Meckling, 1976), examines the theory of the firm. The study claims that the extent of monitoring by shareholders is a function of the amount of shares held or the spread of the shares among the shareholders. Hope (2013), investigates large shareholders. The study claims that an increase in the shareholding of the second-largest shareholder empowers the shareholder to effectively prevent the largest shareholder from exploiting minority shareholders. It also claims that it is concerned with the majority shareholders' conflicts with the minority shareholders. Such conflict is otherwise known as Type II agency conflicts or horizontal-agency-cost (Lei, Lin, \& Wei, 2013). It is a situation, whereby, large shareholders monitor one another and as a result, improve the performance of the company by reducing expropriation of company's assets (Pagano \& Roell, 1998). The expectation following discussion is that increase in the stake of a second-largest shareholder is likely to protect the interest of the minority shareholders. Thereby, there will be more demand for monitoring. The study, therefore, considers related hypotheses as follows:

$\mathbf{H}_{2 \mathrm{a}} \quad$ Horizontal-agency-costs positively influences the demand for monitoring mechanisms 
http://dx.doi.org/10.15405/epsbs.2016.08.37

eISSN: 2357-1330 / Corresponding Author: Rachael Oluyemisi Arowolo

Selection and peer-review under responsibility of the Organizing Committee of the conference

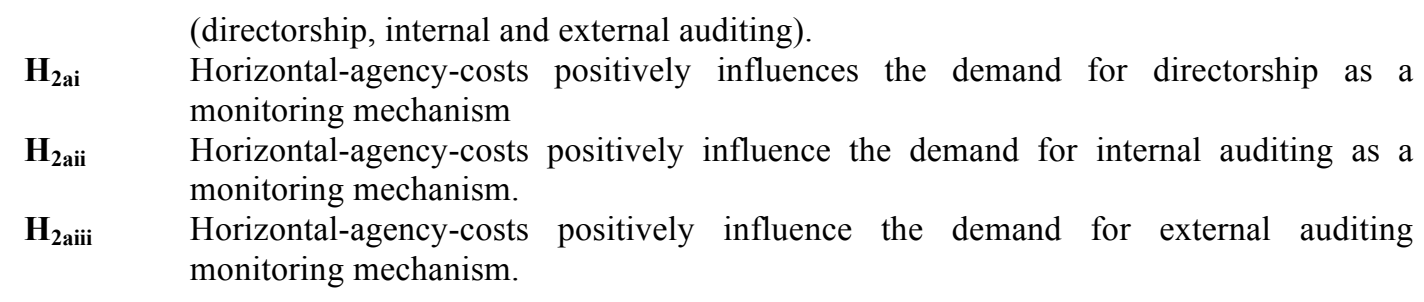

\section{Methodology}

\subsection{Sample}

This study used the quantitative method to analyse data extracted from the annual reports of 111 Nigerian non-financial listed companies. The annual reports were collected from the Nigerian Stock Exchange. The researchers also used questionnaires to obtain data on internal auditing as the information is not available on annual reports. Both the managerial ownership (MO) and horizontalagency-costs (BOC) are obtainable from the annual reports and are continuous data. The dimensions of the dependent variable, monitoring mechanisms (MC), except for the internal auditing are available from annual reports and are continuous data.

\subsection{Measurement}

The dependent variable, monitoring mechanisms (MC) is measured by summing up the costs of non-executive directors' remunerations (NEDIR), the costs of internal auditing (IAC) and external audit fees (EAC) all in Nigerian currency, naira ( $)$.

The measurement for the managerial ownership (MO) is the proportion of the shares held by management to company's total share. The horizontal-agency-costs (BOC) measurement is the change in the shareholding of BOC, current year compared to the immediately preceding year.

The control variables company performance is the proportion of the interest before tax and interest to total assets. The company complexity (CY) is the number of subsidiaries held by the company. The panel data model for the study is as shown below:

Where:

$$
\mathrm{MC}_{\mathrm{it}}=\alpha_{\mathrm{it}}+\beta_{1} \mathrm{MO}_{\mathrm{it}}+\beta_{2} \mathrm{BOC}_{\mathrm{it}}+\beta_{3} \mathrm{FP}_{\mathrm{it}}+\beta_{4} \mathrm{CY} \mathrm{Y}_{\mathrm{it}}+\mu_{\mathrm{it}}+\varepsilon_{\mathrm{it}}
$$

$\begin{array}{lll}\text { MC } & = & \text { Monitoring Cost } \\ \text { MO } & = & \text { Managerial Ownership } \\ \text { BOC } & = & \text { Horizontal-agency-costs } \\ \text { FP } & = & \text { Company Performance } \\ \text { CY } & = & \text { Company's Complexity }\end{array}$

\section{Results and Discussion}

The researchers administered 332 questionnaires in 166 Nigerian non-financial listed companies. The researchers gave one questionnaire to the internal auditor and another one to either the head of accounts or the company secretary. The expectation was to receive at least one back from each company. Nigerian Stock Exchange released the annual reports for periods 2010 to 2012 on demand.

Out of 117 questionnaires received only 111 for which there were corresponding annual reports were analysed. The researchers used SPSS 22 to run descriptive analysis and Stata to test the 
hypotheses using panel data regression technique. The male respondents are $80.2 \%$, and females are 19.8\%. Of these respondents, 48.6\% are Internal Auditors, 38.7\% Accountants and 12.6\% Company Secretaries. $46.8 \%$ of them have been with their companies for less than 5 years, $36 \%$ for 6 to 10 years.

The F-test for the model suggests statistical significance. The mean value of the independent variables, managerial ownership, and horizontal-agency-costs are respectively 0.109 and 3.769. The minimum scores for the two variables are 0 and -9.26 respectively and maximum scores of 59.17 and 13.09. Thus, the model meets the minimum requirement for multivariate analysis. $66.4 \%$ of the companies are with managerial ownership. $4.5 \%$ changes in the stake of horizontal-agency-costs were negative; $85.6 \%$ were with no change possibly due to the persisting financial crisis and $9.9 \%$ were with positive changes.

Tables 1 and 2 show the results of the regression model ran using Stata. The results present collinearity, multicollinearity, variance inflation factors (VIF) and tolerance of the study. The VIF is below 5 and tolerance is above 0.2. Table 2 reveals that the variables are not highly correlated with one another. All the correlations values are well below 0.9. Hence, this study can, therefore, conclude that there is no multicollinearity problem for variables that this paper examines.

Table 1.Variance Inflation Factors (VIF)

\begin{tabular}{lcc}
\hline Variable & VIF & 1/VIF \\
\hline Managerial Ownership & 1.01 & 0.985 \\
Horizontal-agency-costs & 1.00 & 0.998 \\
Company Performance & 1.02 & 0.979 \\
Company's Complexity & 1.01 & 0.992 \\
Mean VIF & 1.01 & \\
\hline
\end{tabular}

Table 2. Pearson Correlation

\begin{tabular}{|c|c|c|c|c|c|}
\hline & $\begin{array}{l}\text { Monitoring } \\
\text { Mechanisms }\end{array}$ & $\begin{array}{l}\text { Managerial } \\
\text { Ownership }\end{array}$ & $\begin{array}{l}\text { Second- } \\
\text { largest } \\
\text { Shareholders }\end{array}$ & $\begin{array}{l}\text { Company } \\
\text { Performance }\end{array}$ & Company's Complexit \\
\hline Monitoring Mechanisms & 1.000 & & & & \\
\hline Managerial Ownership & -0.209 & 1.000 & & & \\
\hline Horizontal-agency-costs & 0.123 & 0.009 & 1.000 & & \\
\hline Company Performance & 0.208 & -0.116 & 0.029 & 1.000 & \\
\hline Company's Complexity & 0.434 & -0.022 & 0.027 & -0.079 & 1.000 \\
\hline
\end{tabular}

The study ran the data for regression analysis using the pool, fixed effect, random effect and panelcorrected standard errors (PSCEs). The researchers choose to use the results from PSCEs because of its robustness nature (Beck \& Katz, 1995). Also, the model could correct for heteroscedasticity and autocorrelation [29]. The result is as shown in Table 3. The results suggest that the managerial ownership (MO), horizontal-agency-costs (BOC) and the two control variables (company performance and complexity) are significant predictor variables for monitoring mechanisms (MC). The results show 
http://dx.doi.org/10.15405/epsbs.2016.08.37

eISSN: 2357-1330 / Corresponding Author: Rachael Oluyemisi Arowolo

Selection and peer-review under responsibility of the Organizing Committee of the conference

that $\mathrm{MO}(\mathrm{b}=-0.046, \mathrm{z}=-12.27)$ significantly affects the $\mathrm{MC}$ at $1 \%$. It indicates that a unit increase in MO results in a decrease of 0.046 in MC. Type II agency problem, horizontal-agency-costs ( $b=0.0225$, $\mathrm{z}=1.8$ ) significantly affects $\mathrm{MC}$ at $10 \%$. It indicates that a unit increase in the stake of the horizontalagency-costs will yield an increase of 0.0225 in MC. The two control variables, company performance $(\mathrm{FP}-\mathrm{b}=2.649, \mathrm{z}=2.63)$ and company complexity $(\mathrm{CY}-\mathrm{b}=0.263, \mathrm{z}=15.4)$ also affects $\mathrm{MC}$ significantly at 1\%. A unit increase in FP will result in 2.649 increase in MC while a unit increase in CY yields an increase of 0.263 in MC. The z-tests as already indicated above and in the table confirm further the significance of the relationship between the variables as all are above the threshold of 1.65. The pvalues are also all below $5 \%$ for $\mathrm{MO}, \mathrm{BOC}, \mathrm{FP}$ and $\mathrm{CY}$.

Table 3. Panel Data Regression Results

\begin{tabular}{lllll}
\hline MC & Coef. & Std. Err. & $\mathrm{z}$ & $\mathrm{P}>\mathrm{z}$ \\
\hline Managerial Ownership & -0.046 & 0.004 & -12.27 & 0.000 \\
Horizontal-agency-costs & 0.225 & 0.125 & 1.8 & 0.072 \\
Company Performance & 2.649 & 1.007 & 2.63 & 0.009 \\
Company's Complexity & 0.263 & 0.017 & 15.4 & 0.000 \\
cons & 2.760 & 0.216 & 12.78 & 0.000 \\
\hline
\end{tabular}

The result supports hypothesis 1 that managerial ownership (MO) negatively influences the demand for monitoring mechanisms, directorship, internal and external auditing. This conforms to the earlier studies in the developed and transiting countries (Mustapha \& Che-Ahmad, 2011; Eng \& Mak, 2003). Both ownership and control are entrenched in the same person(s). Hence, there is no need for monitoring by another party. $89.5 \% \mathrm{MO}$ in the study is below $5 \%$. Hence, there may be no urge to demand monitoring as the owner-manager becomes more efficient controlling the company assets and is with less information asymmetry.

The result also supports hypothesis 2 that Horizontal-agency-costs positively influences the demand for monitoring mechanisms, directorship, internal and external auditing. The result conforms to the findings of Hope, Langli, and Thomas (2012). The increase in the shareholding results in an increase in the ability and willingness of the second-largest holder to monitor the largest shareholder (ownermanager). Thereby, monitoring costs increase with the increase in the demand for monitoring by the horizontal-agency-costs. Protection of minority shareholders is emphasized by Nigerian SEC 2011, and monitoring by the second-largest shareholders is a good tool to achieve this.

There are extant literature on monitoring mechanisms (Hope, 2013; Ali \& Lesage, 2013; Anderson et al., 1993). However, none except Mustapha and Che-Ahmad (2011) tests the impact of managerial ownership on monitoring mechanisms (MC) as a combination of directorship, internal and external auditing. None, to the best of the knowledge of the researchers, has tested the impact of the second largest shareholders on monitoring mechanisms (MC) as a combination of directorship, internal and external auditing. The academic community is positioned to investigate more into this as it affects Sub-Saharan African considering the difference in their culture, politics, economy and other possible endogeneity factors that might affect this result. 
To check for robustness of the model, the researchers subjected the data to further test using the structural equation model. The result confirms further the significance of the variables, managerial ownership (MO), horizontal-agency-costs (BOC), company performance (FP) and company complexity (CY) to the monitoring mechanisms (MC). All the $\mathrm{z}$ values are above 1.65 and $\mathrm{p}$-values significant at $1 \%$ except BOC, which is significant at $10 \%$.

\section{Conclusion}

This study adds to the literature on managerial ownership and agency conflicts among shareholders due to the likelihood that it may be the first paper that combines the three dimensions of monitoring mechanisms (directorship, internal and external auditing) in Sub-Saharan Africa, Nigeria in particular. The study finds that managerial ownership is negatively significant while horizontal-agency-cost is positively significant in the relationship with monitoring mechanisms (directorship, internal and external auditing). The primary contribution of the study is that managerial ownership and horizontalagency-costs significantly impact monitoring mechanisms and also complement the monitoring mechanisms. These findings are useful for the investors, board of directors, regulatory bodies and government to ensure the protection of minority shareholders. The data used for this study is limited to non-financial listed companies. Future studies may, therefore, consider financial listed companies.

\section{References}

Ali, C. Ben, \& Lesage, C. (2013). Audit pricing and nature of controlling shareholders: Evidence from France. China Journal of Accounting Research, 6(1), 21-34.

Amran, N. A., \& Che-Ahmad, A. (2013). Effects of Ownership Structure on Malaysian Companies Performance. Asian Journal of Accounting and Governance, 60(4), 51-60.

Anderson, D., Francis, J. R., \& Stokes, D. J. (1993). Auditing, directorships and the demand for monitoring. Journal of Accounting and Public Policy, 12(4), 353-375.

Anderson, R. C., Mansi, S. A., \& Reeb, D. M. (2003). Founding Family Ownership and the Agency Cost of Debt. Journal of Financial Economics, 68(2), 263-285.

Azim, M. I. (2012). Corporate governance mechanisms and their impact on company performance: A structural equation model analysis. Australian Journal of Management, 37(3), 481-505.

Beck, N., \& Katz, J. N. (1995). What to do (and not to do) ith Time-Series Cross-Section Data. The American Political Science Review, 89(3), 634-647.

Chen, G., Firth, M., Gao, D. N., \& Rui, O. M. (2006). Ownership structure, corporate governance, and fraud: Evidence from China. Journal of Corporate Finance, 12(3), 424-448. doi:10.1016/j.jcorpfin.2005.09.002

Choi, J.-H., Lee, J., \& Sonu, C. H. (2013). Determinants of human resource investment in internal controls. China Journal of Accounting Research, 6(3), 167-185.

Connelly, B. L., Hoskisson, R. E., Tihanyi, L., \& Certo, S. T. (2010). Ownership as a Form of Corporate Governance. Journal of Management Studies, 47(8), 1561-1589.

Ehikioya, B. I. (2009). Corporate governance structure and firm performance in developing economies: evidence from Nigeria. Corporate Governance, 9(3), 231-243.

Eng, L. ., \& Mak, Y. . (2003). Corporate Governance and Voluntary Disclosure. Journal of Accounting and Public Policy, 22, 325-345.

He, L., \& Ho, S.-J. K. (2010). Monitoring Costs, Managerial Ethics and Corporate Governance: A Modeling Approach. Journal of Business Ethics, 99(4), 623-635.

Hope, O.-K. (2013). Large shareholders and accounting research. China Journal of Accounting Research, 6(1), $3-$ 20.

Hope, O.-K., Langli, J. C., \& Thomas, W. B. (2012). Agency conflicts and auditing in private firms. Accounting, Organizations and Society, 37(7), 500-517.

Huson, M. R., Parrino, R., \& Starks, L. T. (2001). Internal Monitoring Mechanisms and CEO Turnover : A LongTerm Perspective. The Journal of Finance, 56(6), 2265-2297.

Jensen, M. C., \& Meckling, W. H. (1976). Theory of the Firm : Managerial Behavior, Agency Costs and Ownership Structure. Journal of Financial Economics, 3(4), 305-360.

Jusoh, M. A., \& Che-Ahmad, A. (2014). Equity Ownership , Audit Quality and Firm Performance in Malaysia 
http://dx.doi.org/10.15405/epsbs.2016.08.37

eISSN: 2357-1330 / Corresponding Author: Rachael Oluyemisi Arowolo

Selection and peer-review under responsibility of the Organizing Committee of the conference

using Generalized Least Square Estimations Technique. Journal of Emerging Issues in Economics, Finance and Banking (JEIEFB), 3(1), 976-991.

Kao, L., Chiou, J., \& Chen, A. (2004). The Agency Problems, Firm Performance and Monitoring Mechanisms : the evidence from collateralised shares in Taiwan. Blackwell Publishing Ltd, 12(3), 389-402.

Lei, Q., Lin, B., \& Wei, M. (2013). Types of agency cost, corporate governance and liquidity. Journal of Accounting and Public Policy, 32(3), 147-172.

Mustapha, M., \& Che-Ahmad, A. (2011). Agency theory and managerial ownership: evidence from Malaysia. Managerial Auditing Journal, 26(5), 419-436.

Mustapha, M., \& Che-Ahmad, A. (2013). Blockholders and Corporate Monitoring Costs : Evidence from Malaysia. International Journal of Economics and Management, 7(1), 28-44.

Nworji, I. D., Adebayo, O., \& Adeyanju, O. D. (2011). Corporate Governance and Bank Failure in Nigeria : Issues , Challenges and Opportunities. Research Journal of Finance and Accounting, 2(2).

Pagano, M., \& Roell, A. (1998). The Choice of Stock Ownership Structure : Agency Costs , Monitoring, and the Decision to go Public. The Quarterly Journal of Economics, 113(1), 187-225.

Reuer, J. J., Tong, T. W., \& Wu, C.-W. (2012). A Signaling Theory of Acquisition Premiums: Evidence from IPO Targets. Academy of Management Journal, 55(3), 667-683.

SEC. Securities and Exchange Commission Code of Corporate Governance (2011).

Slyke, D. M. Van. (2006). Agents or Stewards: Using Theory to Understand the Government-Nonprofit Social Service Contracting Relationship. Journal of Public Administration Research and Theory, 17(2), 157-187.

Uadiale, O. M. (2010). The Impact of Board Structure on Corporate Financial Performance in Nigeria. International Journal of Business and Management, 5(10), 155-166. 